\title{
Activation of the interferon pathway is dependent upon autoantibodies in African-American SLE patients, but not in European-American SLE patients
}

\author{
Kichul Ko' ${ }^{1}$, Yelena Koldobskaya ${ }^{1}$, Elizabeth Rosenzweig ${ }^{1}$ and Timothy B. Niewold ${ }^{2}$ * \\ ' Section of Rheumatology, Gwen Knapp Center for Lupus and Immunology Research, University of Chicago, Chicago IL, USA \\ 2 Department of Immunology, Division of Rheumatology, Mayo Clinic, Rochester, MN, USA
}

Edited by:

Fabrizio Mattei, Istituto Superiore di

Sanità, Italy

\section{Reviewed by:}

Dalil Hannani, Institut de Cancérologie

Gustave Roussy - INSERM U1015,

France

Kamil R. Kranc, University of

Edinburgh, UK

${ }^{*}$ Correspondence:

Timothy B. Niewold, Department of Immunology, Division of

Rheumatology, Mayo Clinic, 200 1st

Street SW, Guggenheim Building

3-42, Rochester, MN 55905, USA

e-mail: niewold.timothy@mayo.edu

Background: In systemic lupus erythematosus (SLE), antibodies directed at RNA-binding proteins (anti-RBP) are associated with high serum type I interferon (IFN), which plays an important role in SLE pathogenesis. African-Americans (AA) are more likely to develop SLE, and SLE is also more severe in this population. We hypothesized that peripheral blood gene expression patterns would differ between AA and European-American (EA) SLE patients, and between those with anti-RBP antibodies and those who lack these antibodies.

Methods: Whole blood RNA from 33 female SLE patients and 16 matched female controls from AA and EA ancestral backgrounds was analyzed on Affymetrix Gene 1.0 ST gene expression arrays. Ingenuity Pathway Analysis was used to compare the top differentially expressed canonical pathways amongst the sample groups. An independent cohort of 116 SLE patients was used to replicate findings using quantitative real-time PCR (qPCR).

Results: Both $A A$ and EA patients with positive anti-RBP antibodies showed overexpression of similar IFN-related canonical pathways, such as IFN Signaling $\left(P=1.3 \times 10^{-7}\right.$ and $6.3 \times 10^{-11}$ in AA vs. EA respectively), Antigen Presenting Pathway $\left(P=1.8 \times 10^{-5}\right.$ and $\left.2.5 \times 10^{-6}\right)$, and a number of pattern recognition receptor pathways. In anti-RBP negative (RBP-) patients, EA subjects demonstrated similar IFN-related pathway activation, whereas no IFN-related pathways were detected in RBP-AA patients. GPCR validation confirmed similar results.

Conclusion: Our data show that IFN-induced gene expression is completely dependent on the presence of autoantibodies in AA SLE patients but not in EA patients. This molecular heterogeneity suggests differences in IFN-pathway activation between ancestral backgrounds in SLE. This heterogeneity may be clinically important, as therapeutics targeting this pathway are being developed.

Keywords: systemic lupus erythematosus, interferon alpha, autoantibodies, ancestral background, interferon gamma

\section{INTRODUCTION}

Systemic lupus erythematosus (SLE) is a heterogeneous disease characterized by complex genetic contributions and activation of a number of immune system pathways (1-3). Recent advances in human genetic studies have helped us better understand the immunopathogenesis of the disorder $(4,5)$. Multiple candidate gene association studies and genome wide association studies have led to discovery of more than 30 susceptibility loci throughout the whole genome, most of which are involved in three main pathways

Abbreviations: AA, African-American; ANA, antinuclear antibodies; Anti-dsDNA, anti-double-stranded DNA; Anti-RBP, anti-RNA-binding protein; Anti-RNP, antiribonucleoprotein; Anti-Sm, anti-smith; EA, European-American; HA, HispanicAmerican; IFIGs, IFN-inducible genes; IFN, interferon; IPA, ingenuity pathway analysis; PRRs, pattern recognition receptors; $\mathrm{QPCR}$, quantitative real-time PCR; $\mathrm{RBP}+$, anti-RBP antibody positive; RBP-, anti-RBP antibody negative; RLRs, RIGI like receptors; SLE, systemic lupus erythematosus; TLR, toll-like receptor; UCMC, University of Chicago Medical Center. in lupus pathogenesis: abnormal clearance of nuclear debris and immune complexes, over-activation of innate immune system through Toll-like receptor (TLR) and type I interferon (IFN) signaling, and aberrant adaptive immune response through $\mathrm{B}$ and $\mathrm{T}$ cell signaling $(6,7)$. Moreover, gene expression microarray studies have been instrumental in defining important aspects of the complex immunological pathogenesis in human subjects $(8,9)$. Several gene expression analyses in SLE have found up-regulation of IFNinducible genes (IFIGs) in more than $50 \%$ of patients (10-13), and others have shown differential expression of genes involved in several pathways including inflammation, apoptosis, DNA repair, and $\mathrm{T}$ cell activation $(12,14-17)$.

Interferon- $\alpha$ is a pleiotropic type I IFN which plays a key pathogenic role in lupus development (18). It is an anti-viral cytokine which is regulated by endosomal pattern recognition receptors (PRRs) such as TLRs or cytosolic PRRs like RIG-I like receptors (RLRs) $(18,19)$. It has the potential to break self-tolerance by 
inducing dendritic cell differentiation which in turn leads to activation of autoreactive $\mathrm{T}$ and $\mathrm{B}$ cells, thus linking innate and adaptive immune systems $(20,21)$. IFN- $\alpha$ is a heritable risk factor in $\operatorname{SLE}(22,23)$ and some people who have received recombinant human IFN- $\alpha$ as a treatment for viral hepatitis $\mathrm{C}$ or malignancy have developed de novo SLE which resolves upon discontinuation of the IFN- $\alpha$ treatment (24). These data strongly support a causal role for IFN- $\alpha$ in SLE pathogenesis. Increased activity of IFN$\alpha$ has been associated with presence of various SLE-associated autoantibodies, both anti-double-stranded DNA (anti-dsDNA) and anti-RNA-binding protein (anti-RBP) antibodies along with different organ involvement such as hematologic, renal, and central nervous systems $(10,25,26)$. However, longitudinal studies have not confirmed the association between increases in IFIG expression and disease flare $(27,28)$. It seems that patients with high IFN- $\alpha$ have more severe disease and a higher rate of flare on average, but the changes in IFN- $\alpha$ levels in circulation do not correlate closely or quantitatively with changes in measures of disease activity over time.

Systemic lupus erythematosus is both more prevalent and more severe in African-American (AA) populations than in EuropeanAmerican (EA) populations, and disease manifestations are variable amongst different ancestral backgrounds (29-32). AA and Hispanic-American (HA) patients are likely to have more active SLE, with an earlier age at onset, than EA patients $(31,32)$. Antiribonucleoprotein (anti-RNP) and anti-Smith (anti-Sm) antibodies are more prevalent in AA patients than in EA and HA (30, 32 ), and a number of genetic variants are associated with autoantibody profiles in different ancestral groups $(33,34)$. Moreover, compared to EA patients, HA, and AA patients have a higher incidence of SLE-related renal disease, associated with anti-dsDNA and anti-RNP antibodies $(31,35)$. Additionally, some of the genetic factors associated with SLE are not shared between AA and EA patients (36-39). These data all support the idea that molecular and biological differences should exist in SLE patients of different ancestral backgrounds. We have shown that overall serum IFN- $\alpha$ activity is higher in SLE patients of non-European ancestry as compared to European ancestry, either directly or indirectly through an increased prevalence of anti-RBP antibodies (40, 41). In this study, we compare peripheral blood gene expression between AA and EA SLE patients taking into account the differences in autoantibody profile, and we find a striking difference in the activation of the IFN pathway between the two groups.

\section{MATERIALS AND METHODS \\ PATIENTS, SAMPLES, AND DATA COLLECTION}

Serum samples were obtained from 149 female SLE patients from the University of Chicago Medical Center (UCMC) $(n=119)$ and NorthShore University Health System $(n=30)$. All cases fulfilled the American College of Rheumatology criteria for the diagnosis of $\operatorname{SLE}(1,42)$, and the data regarding the presence or absence of these criteria as well as of SLE-associated autoantibodies [anti-nuclear antibodies (ANA), and anti-Ro, anti-La, anti-Sm, anti-RNP, and anti-dsDNA antibodies] were available for all patients. Forty-nine unrelated females who were screened by medical record review for the absence of autoimmune disease were used as controls. They were of similar age $(P=0.21)$ as the SLE cases. All subjects provided informed consent, and the study was approved by the institutional review boards at the Mayo Clinic and University of Chicago.

\section{DETECTION OF AUTOANTIBODIES}

Antibodies to Ro, La, Sm, and RNP for all samples were measured by ELISA methods (INOVA Diagnostics, San Diego, CA, USA) at UCMC at the time of serum and RNA sampling, and standard clinical laboratory cutoff points were used to categorize them as positive or negative. Anti-dsDNA antibodies were measured using Crithidia luciliae immunofluorescence at UCMC, and detectable fluorescence was considered positive.

\section{GENE EXPRESSION ANALYSIS}

Thirty-three SLE cases and 16 age-matched controls were selected for microarray gene expression analysis. The cases were subdivided into AA and EA patients, and those with positive anti-RBP antibodies and those without as described in Table 1. Whole blood from the subjects was collected in PAX gene tubes (Qiagen), and RNA was purified in spin columns per manufacture recommendations. The RNA was analyzed on Affymetrix Gene 1.0 ST gene expression arrays, which were run in the University of Chicago Microarray Core facility. These intensity data were normalized through Affymetrix Expression Console software. Data from the microarray experiment have been deposited in the GEO database, accession number GSE50635.

Quantitative real-time PCR (qPCR) was used to validate the hypotheses generated from the microarray data with an independent replication cohort. The RNA of whole blood from 60 AA SLE patients, 47 anti-RBP antibody positive (RBP+), and 13 anti-RBP antibody negative (RBP-), and 56 EA SLE patients, $21 \mathrm{RBP}+$ and $24 \mathrm{RBP}$ - along with $25 \mathrm{AA}$ and 8 EA controls was purified using Qiagen RNeasy kit. cDNA was synthesized from total mRNA, and qPCR was used to measure relative transcript expression using SYBR Green dye on an ABI 7900HT thermal cycler.

\section{STATISTICAL ANALYSIS}

For each ancestry, the anti-RBP antibody status was used as a dichotomous variable, and each subgroup was compared to respective controls from the same ancestral background. Following normalization, the mean microarray gene expression values along

Table 1 | Samples and data collection for microarray analysis*.

\begin{tabular}{|c|c|c|c|c|}
\hline & & \multicolumn{2}{|c|}{ SLE cases $^{* *}$} & \multirow{2}{*}{$\begin{array}{l}\text { Non-autoimmune } \\
\text { controls }\end{array}$} \\
\hline & & RBP+ & RBP- & \\
\hline European-American & Female & 8 & 8 & 8 \\
\hline African-American & Female & 9 & 8 & 8 \\
\hline
\end{tabular}

*There was no difference in age amongst the groups.

${ }^{*}$ All SLE cases fulfilled the ACR criteria for SLE. Anti-RBP (anti-Ro, anti-La, antiSm, and anti-RNP) antibodies were measured by ELISA, and anti-dsDNA antibody levels were measured using Crithidia luciliae immunofluorescence.

$R B P+$, anti-RNA-binding-protein (RBP) antibody positive; RBP-, RBP antibody negative. 
with standard deviations were calculated for each subgroup and used to calculate the fold changes between subjects and controls. Values were compared between the groups using the two-tailed Student's unpaired $t$-test. Similar comparisons were made with the qPCR data, but this time, all group results were expressed in medians and compared using Mann-Whitney tests as they did not follow Gaussian distributions. For both microarray and qPCR analyses, $P$ values less than 0.05 were considered significant.

\section{CANONICAL PATHWAY ANALYSIS}

From the microarray data, the differentially expressed genes with a cutoff $P$ value of 0.05 along with their respective fold changes were analyzed further through Ingenuity Pathway Analysis (IPA) (Ingenuity ${ }^{\circledR}$ Systems, www.ingenuity.com) to compare the top canonical pathways amongst the sample groups (Table 1). The IPA canonical pathway analysis identified the pathways from the IPA Knowledge Base that were most significant to the data set. The significance of the association between the data set and the canonical pathway was measured in two ways: (1) A ratio of the number of molecules from the data set that map to the pathway divided by the total number of molecules that map to the canonical pathway was displayed. (2) Fisher's exact test was used to calculate a $P$ value determining the probability that the association between the genes in the dataset and the canonical pathway was explained by chance alone.

\section{RESULTS \\ DEMOGRAPHICS AND PRESENCE OF ANA AND ANTI-dsDNA ANTIBODIES}

The average age of all subjects included in the microarray portion of the study was $43.5 \pm 10.6$ years. When the subjects and controls were divided into subgroups according to ancestry and the presence of anti-RBP antibodies (Table 1), there was no statistical difference in age amongst the subgroups including controls. There was lower prevalence in anti-dsDNA antibodies in RBP-AA patients $(77 \%$ of RBP+ vs. $31 \%$ of RBP- had anti-dsDNA antibodies, $P=0.005)$. In EA subjects, this difference was much less pronounced, and was not statistically significant $(66 \%$ of $\mathrm{RBP}+$ vs. $54 \%$ of RBP - had anti-dsDNA antibodies, $P=0.4)$. This is in concordance with our previous large-scale analyses in SLE, in which we have also found that anti-RBP and anti-dsDNA antibodies are more correlated in AA as compared to EA SLE patients (40). All subjects were female and all tested positive for ANA.

\section{IFN-RELATED CANONICAL PATHWAY ACTIVATION IN AA vs. EA SLE PATIENTS}

Top 10 canonical pathways from each subgroup are shown in Table 2. Many immune system associated pathways were associated with the cases, and similar to previous studies, type I IFN-related pathways were the most differentially expressed when comparing cases vs. controls except in RBP-AA group. We examined in greater detail the six canonical pathways which were type I IFN-related across patients from the two different ancestral backgrounds studied. As shown in Table 3, the microarray analysis of all SLE cases vs. controls demonstrated all six IFN-related canonical pathways significantly involved. The same pattern was also observed for all EA cases vs. controls. However, to our surprise, the associations between the IFN-related canonical pathways and AA SLE cases were not as strong as only three out of six pathways were found to be significant. This is despite that fact that high circulating levels of type I IFN are more common in AA SLE patients (40).

\section{IFN-RELATED CANONICAL PATHWAY ACTIVATION IS NOT SEEN IN RBP- AA PATIENTS}

To explore this further, we looked at the associations between IFNrelated canonical pathways within SLE patient subgroups stratified by both ancestry and the presence or absence of anti-RBP antibodies. As shown in Table 4, all six type I IFN-related pathways were activated in both AA and EA RBP+ patients. The key pathway difference was found between AA and EA patients who were RBP-. RBP - EA patients demonstrated activation of all six IFN-related canonical pathways, whereas not a single type I IFN pathway was significantly involved in the RBP-AA patients.

\section{IFN-INDUCED GENE EXPRESSION PATHWAY DIAGRAMS IN AA vs. EA PATIENTS}

In Figure 1, we show pathway diagrams generated in IPA software of the type I and type II IFN pathways, with genes that were upregulated in cases vs. controls shaded red. It is striking that none of the genes illustrated downstream of the type I and type II IFN receptors are up-regulated in the $\mathrm{RBP}-\mathrm{AA}$ patients, while in the $\mathrm{RBP}-$ EA patients, many IFN-induced genes are over-expressed. It is also interesting that STAT1 over-expression is observed in the $\mathrm{RBP}+$ subjects regardless of ancestral background, and this is not observed in the RBP- patients from either ancestral background.

\section{REPLICATION STUDY CONFIRMS THE DEPENDENCE OF IFN-INDUCED GENE EXPRESSION UPON PRESENCE OF ANTI-RBP ANTIBODIES IN AA PATIENTS, BUT NOT EA PATIENTS}

Three IFIGs (IFIT1, MX1, and PKR) were selected for qPCR analysis to replicate the microarray observation with regards to the association between anti-RBP antibodies and IFN-related gene expression across different ancestral backgrounds. These genes were quantified in whole blood mRNA from an independent cohort of 116 SLE patients and 33 controls. As shown in Figure 2, the pattern observed mirrors the microarray data. All three genes were up-regulated in both $\mathrm{EA}$ and $\mathrm{AA} \mathrm{RBP}+$ patients. In the $\mathrm{RBP}$ - patients, there is essentially no increase in IFN-induced gene expression in AA patients, while the expression of these genes, in particular PKR, is increased in the RBP- EA SLE patients. Because anti-dsDNA antibodies have been associated with high IFN- $\alpha$ (25, $26)$, it is important to determine whether anti-dsDNA antibodies are contributing to the induction of IFN-induced gene expression we observe in our RBP- EA patients. As noted above, the $\mathrm{RBP}-\mathrm{EA}$ subjects were more likely to have anti-dsDNA antibodies than the RBP-AA subjects. When we looked at the RBP negative patients in the $\mathrm{qPCR}$ replication cohorts with regard to presence or absence of anti-dsDNA antibodies, there was no significant difference in IFIT1, MX1, or PKR over-expression in the AA subjects. In RBP - EA patients, however, over-expression of IFN-induced genes (IFIT1 and PKR) was observed in the anti-dsDNA antibody positive patients but not in the anti-dsDNA antibody negative group (Figure 3). Thus, in RBP- EA subjects, the anti-dsDNA 
Table 2 |Top 10 canonical pathways from each subgroup vs. matching controls through IPA from microarray data.

\begin{tabular}{|c|c|c|c|c|c|c|}
\hline All cases & All EA & All AA & EA RBP+ & EA RBP- & AA RBP+ & AA RBP- \\
\hline EIF2 signaling & Interferon signaling & EIF2 signaling & $\begin{array}{l}\text { Interferon } \\
\text { signaling }\end{array}$ & $\begin{array}{l}\text { Antigen } \\
\text { presentation } \\
\text { pathway }\end{array}$ & EIF2 signaling & $\begin{array}{l}\text { Regulation of IL-2 } \\
\text { expression in } \\
\text { activated and } \\
\text { anergic } T \\
\text { lymphocytes }\end{array}$ \\
\hline $\begin{array}{l}\text { Antigen presentation } \\
\text { pathway }\end{array}$ & $\begin{array}{l}\text { Role of pattern } \\
\text { recognition } \\
\text { receptors in } \\
\text { recognition of } \\
\text { bacteria and viruses }\end{array}$ & $\begin{array}{l}\text { Angiopoietin } \\
\text { signaling }\end{array}$ & $\begin{array}{l}\text { Antigen } \\
\text { presentation } \\
\text { pathway }\end{array}$ & $\begin{array}{l}\text { Autoimmune } \\
\text { thyroid disease } \\
\text { signaling }\end{array}$ & mTOR signaling & $\begin{array}{l}\text { CD28 signaling in } \\
\text { T helper cells }\end{array}$ \\
\hline $\begin{array}{l}\text { Activation of IRF by } \\
\text { cytosolic pattern } \\
\text { recognition } \\
\text { receptors }\end{array}$ & $\begin{array}{l}\text { Retinoic acid } \\
\text { mediated apoptosis } \\
\text { signaling }\end{array}$ & $\begin{array}{l}\text { Regulation of } \\
\text { elF4 and p70S6K } \\
\text { signaling }\end{array}$ & $\begin{array}{l}\text { Role of pattern } \\
\text { recognition } \\
\text { receptors in } \\
\text { recognition of } \\
\text { bacteria and } \\
\text { viruses }\end{array}$ & $\begin{array}{l}\text { Allograft rejection } \\
\text { signaling }\end{array}$ & $\begin{array}{l}\text { Activation of IRF } \\
\text { by cytosolic } \\
\text { pattern } \\
\text { recognition } \\
\text { receptors }\end{array}$ & $\begin{array}{l}\text { T cell receptor } \\
\text { signaling }\end{array}$ \\
\hline $\begin{array}{l}\text { IL-12 signaling and } \\
\text { production in } \\
\text { macrophages }\end{array}$ & $\begin{array}{l}\text { Activation of IRF by } \\
\text { cytosolic pattern } \\
\text { recognition } \\
\text { receptors }\end{array}$ & $\begin{array}{l}\text { Hypoxia signaling } \\
\text { in the } \\
\text { cardiovascular } \\
\text { system }\end{array}$ & IL-15 production & $\begin{array}{l}\text { Interferon } \\
\text { signaling }\end{array}$ & $\begin{array}{l}\text { Interferon } \\
\text { signaling }\end{array}$ & $\begin{array}{l}\text { Glycosphingolipid } \\
\text { biosynthesis - } \\
\text { globoseries }\end{array}$ \\
\hline TNFR2 signaling & IL-15 production & $\begin{array}{l}\text { Hereditary breast } \\
\text { cancer signaling }\end{array}$ & $\begin{array}{l}\text { Communication } \\
\text { between innate } \\
\text { and adaptive } \\
\text { immune cells }\end{array}$ & $\begin{array}{l}\text { Crosstalk } \\
\text { between } \\
\text { dendritic cells and } \\
\text { natural killer cells }\end{array}$ & TNFR2 signaling & $\begin{array}{l}\text { Reelin signaling in } \\
\text { neurons }\end{array}$ \\
\hline $\begin{array}{l}\text { Production of nitric } \\
\text { oxide and reactive } \\
\text { oxygen species in } \\
\text { macrophages }\end{array}$ & $\begin{array}{l}\text { Autoimmune thyroid } \\
\text { disease signaling }\end{array}$ & $\begin{array}{l}\text { Role of PI3K/AKT } \\
\text { signaling in the } \\
\text { pathogenesis of } \\
\text { influenza }\end{array}$ & $\begin{array}{l}\text { Dendritic Cell } \\
\text { maturation }\end{array}$ & $\begin{array}{l}\text { Type I diabetes } \\
\text { mellitus signaling }\end{array}$ & IL-8 signaling & $\begin{array}{l}\text { Glycosphingolipid } \\
\text { biosynthesis - } \\
\text { neolactoseries }\end{array}$ \\
\hline IL-15 production & $\begin{array}{l}\text { Communication } \\
\text { between innate and } \\
\text { adaptive immune } \\
\text { cells }\end{array}$ & TNFR2 signaling & $\begin{array}{l}\text { Starch and } \\
\text { sucrose } \\
\text { metabolism }\end{array}$ & $\begin{array}{l}\text { Dendritic cell } \\
\text { maturation }\end{array}$ & $\begin{array}{l}\text { P2Y purigenic } \\
\text { receptor signaling } \\
\text { pathway }\end{array}$ & $\begin{array}{l}\text { Mitotic roles of } \\
\text { polo-like kinase }\end{array}$ \\
\hline
\end{tabular}

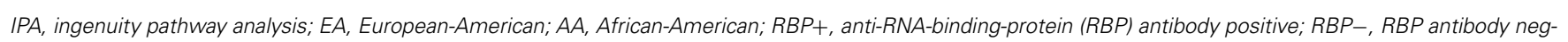
ative; elF2, eukaryotic initiation factor 2; IRF, interferon-regulatory factor; mTOR, mammalian target of rapamycin; TNFR2, tumor necrosis factor receptor 2; elF4, eukaryotic initiation factor $4 ;$ RIG1, retinoic acid-inducible gene 1; PI3K, phosphatidylinositol 3-kinase; OX40=CD134. 


\begin{tabular}{|c|c|c|c|}
\hline & $\begin{array}{l}\text { All SLE cases } \\
(n=33)\end{array}$ & $\begin{array}{l}\text { EA SLE cases } \\
(n=16)\end{array}$ & $\begin{array}{l}\text { AA SLE cases } \\
(n=17)\end{array}$ \\
\hline Interferon signaling & $1.53 \times 10^{-10}$ & $6.55 \times 10^{-12}$ & 0.29 \\
\hline Activation of IRF by cytosolic pattern recognition receptors & $6.14 \times 10^{-5}$ & $2.74 \times 10^{-5}$ & $8.46 \times 10^{-5}$ \\
\hline Role of RIG1-like receptors in antiviral innate immunity & $1.63 \times 10^{-4}$ & $5.85 \times 10^{-7}$ & 0.044 \\
\hline Role of PKR in interferon induction and antiviral response & 0.020 & 0.038 & 0.091 \\
\hline Role of pattern recognition receptors in recognition of bacteria and viruses & 0.0097 & 0.0064 & 0.0011 \\
\hline Communication between innate and adaptive immune cells & 0.0098 & 0.0013 & Not listed \\
\hline
\end{tabular}

IPA, ingenuity pathway analysis; IFN, interferon; SLE, systemic lupus erythematosus; EA, European-American; AA, African-American; IRF, interferon-regulatory factor; $R I G 1$, retinoic acid-inducible gene 1; and PKR, protein kinase $R$.

Table 4 | $P$ values from IPA IFN-related canonical pathways from microarray data.

\begin{tabular}{|c|c|c|c|c|}
\hline & EA RBP+ & EA RBP- & AA RBP+ & AA RBP- \\
\hline Interferon signaling & $5.8 \times 10^{-11}$ & $10.6 \times 10^{-5}$ & $1.3 \times 10^{-7}$ & 0.063 \\
\hline Activation of IRF by cytosolic pattern recognition receptors & $1.1 \times 10^{-6}$ & 0.016 & $2.86 \times 10^{-8}$ & 0.25 \\
\hline Role of RIG1-like receptors in antiviral innate immunity & $2.0 \times 10^{-5}$ & 0.030 & 0.0014 & Not listed \\
\hline Role of PKR in interferon induction and antiviral response & 0.0073 & 0.042 & $9.0 \times 10^{-4}$ & Not listed \\
\hline Role of pattern recognition receptors in recognition of bacteria and viruses & $1.8 \times 10^{-4}$ & 0.028 & $5.8 \times 10^{-4}$ & 0.31 \\
\hline Communication between innate and adaptive immune cells & 0.0043 & 0.0064 & 0.023 & Not listed \\
\hline
\end{tabular}

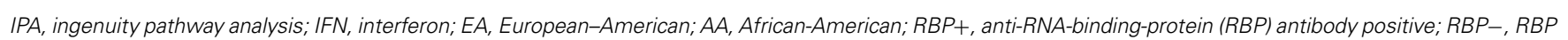
antibody negative; IRF, interferon-regulatory factor; $R I G 1$, retinoic acid-inducible gene 1; and PKR, protein kinase $R$.

antibody status did have an effect on expression of IFIGs, and thus anti-dsDNA antibodies are contributing to the IFN-induced gene expression in this group. Strikingly, anti-dsDNA antibodies had no impact upon IFN-induced gene expression in the RBP- AA group. This was somewhat unexpected and reinforces the idea of RBP antibody dependence in the AA ancestral background.

\section{DISCUSSION}

To our knowledge, this was the first study to show differential gene expression patterns in various subgroups of SLE patients stratified by ancestral background and presence or absence of anti-RBP antibodies. Through microarray whole genome expression with pathway analysis followed by independent qPCR validation, we demonstrated that activation of IFN-related pathways depended on presence of anti-RBP antibodies in AA patients, but not in EA patients. The results also support the model suggested by our previous study in which African ancestry increases the likelihood of SLE-associated autoantibody formation, leading to higher IFN- $\alpha$ activity (41). In the present study, we observe a similar dependence of IFN-induced gene expression upon anti-RBP antibodies in AA patients, and this is not shared with the EA patients, and this novel observation should be confirmed in larger cohorts.

Autoantibody immune complexes present in SLE patients have been implicated as major endogenous IFN-inducers, likely via the endosomal TLR and IFN regulatory factor pathways (43-45). Our data would suggest that the classical activation of IFN-related pathways observed in SLE patients is highly dependent upon anti-RBP antibodies in AA SLE patients, and this dependence is not shared by EA SLE patients. The additional IFN-pathway activation observed in EA subjects is partly due to the presence of anti-dsDNA antibodies. As shown in Figure 3 there are a number of anti-dsDNA and anti-RBP negative EA patients that show over-expression of IFN-induced genes, while in AA SLE patients lacking RBP antibodies, IFN-induced gene expression resembles the AA control population. This heterogeneity in the dependence of IFN-related pathways on autoantibody profile may reflect differential activation of the TLR pathway is SLE patients of different ancestral backgrounds. Anti-RBP antibodies would be expected to activate the RNA-sensing TLRs, while anti-dsDNA antibody immune complexes would be expected to activate TLR 9. Genetic variations in the TLR pathway genes such as IRF5 and IRF7 have been associated with risk of SLE, and with gain of function within the type I IFN pathway $(46,47)$. In our previous study looking at genetic variation at the IRF7/PHRF1 locus, we observed two different high IFN genetic effects in AA subjects, while we saw only one in EA subjects (46). This example demonstrates genetic diversity between world populations in the TLR/IRF system, and could support the idea that this pathway may more prominent in AA subjects and help to explain the findings we report here. Additionally, many of the genetic polymorphisms we have discovered that are associated with increased type I IFN in SLE patients differ between ancestral backgrounds $(34,48)$, and this would also support the idea that the pathway will be more or less prominent in different ancestral backgrounds.

There were EA SLE patients that had increased expression of IFN-induced genes who did not have either anti-RBP or anti-dsDNA autoantibodies. These data suggest that IFN-related pathways may be activated through different mechanisms in this 


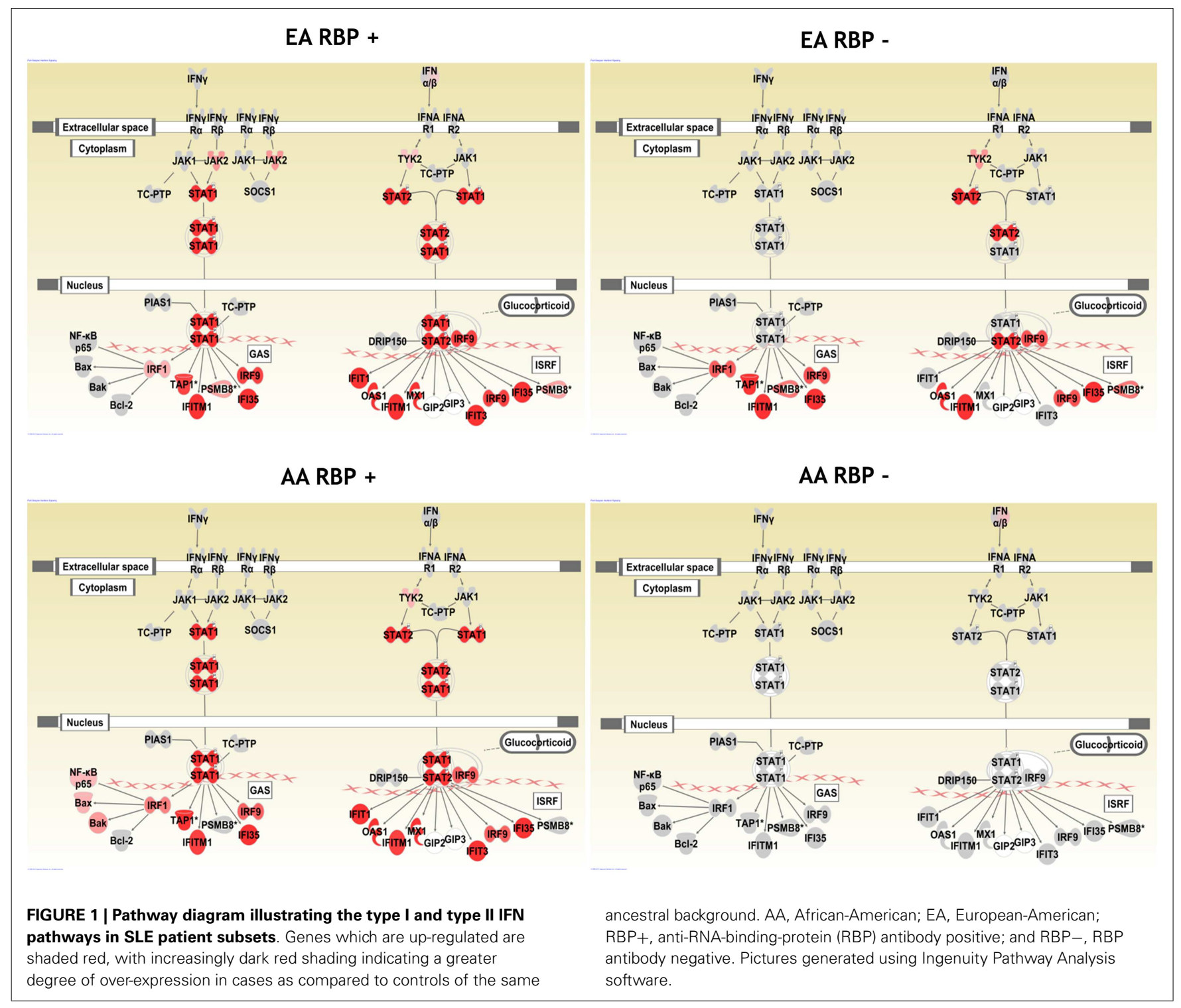

ancestral background. All patients in our study had ANA, and it may be that other nuclear antigen/autoantibody complexes could have triggered the TLR/RLR system leading to IFN-pathway activation in these subjects. It is also possible that other molecules such as HMGB1, which can bind with immune complexes, may be activating an inflammatory cascade in plasmacytoid dendritic cells resulting in activation of IFN pathways (49). Another possibility is that there is an increased sensitivity to IFN signaling or a downstream activator of IFN-induced gene expression in these patients. We have observed some SLE patients in previous studies that have high IFN-induced gene activity in their PBMC with essentially normal circulating type I IFN activity from the same sample $(50,51)$.

This surprising diversity in IFN-pathway activation between different SLE patient subgroups is relevant to clinical care, as therapeutics directed at IFN or IFN-related pathways are being actively developed (52). It seems likely that these IFN-pathway targeting therapeutics will be characterized by heterogeneity in treatment response, and our results may suggest some groups that are likely to be better responders that could be predicted without having to run a gene expression chip prior to therapy. The RBP-AA group is very interesting in this regard, as it seems that this patient group may represent a distinct subset of SLE patients which is not as IFN-dependent as other groups of SLE patients. This may represent a significant difference in disease pathogenesis, which could be important in planning targeted therapies.

\section{CONCLUSION}

Systemic lupus erythematosus is a heterogeneous disease with differences in disease incidence, clinical manifestations, serological findings, and genetic risk factors between ancestral backgrounds $(7,29-32,36-39)$. Perhaps it is not very surprising to find heterogeneity in the activation of molecular pathways between ancestral groups, and it seems likely that different 


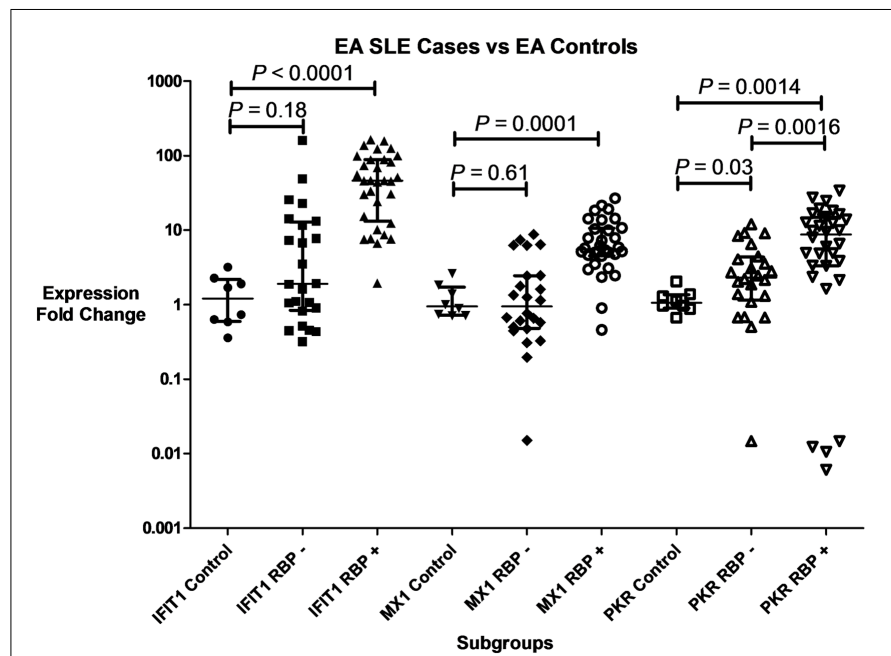

FIGURE 2 |Type I IFN-induced gene expression in SLE patient subgroups and controls. Expression of three genes (IFIT1, MX1, and PKR) are shown in both patients with anti-RNA-binding protein antibodies (RBP+), and those

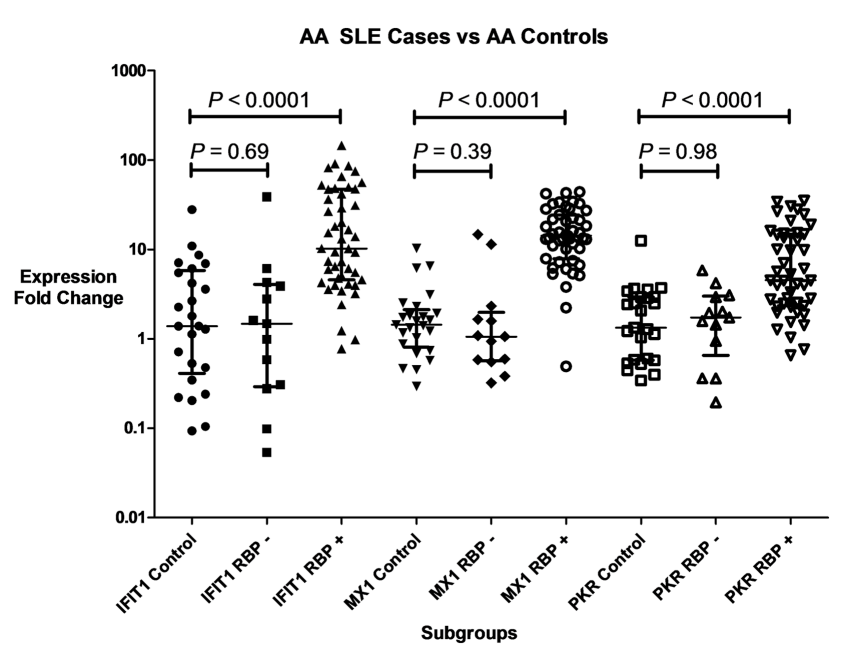

who lack those antibodies (RBP-). Central tendency shown is a median, with error bars representing the interquartile range. $P$ values generated by Mann-Whitney $U$ test.

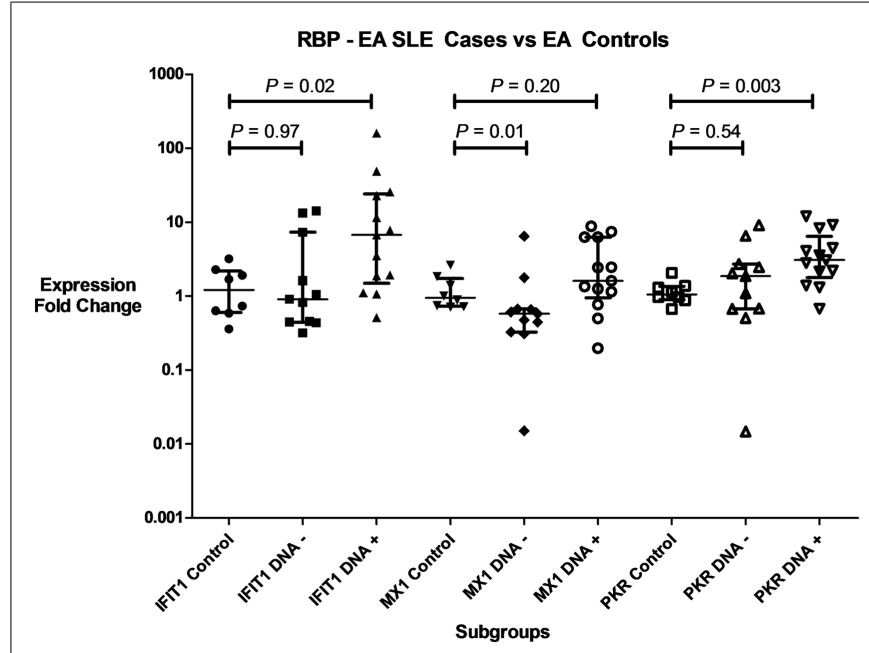

FIGURE 3 |Type I IFN-induced gene expression in RBP-SLE patient subgroups and controls in regards to of anti-dsDNA antibodies.

Expression of three genes (IFIT1, MX1, and PKR) are shown in both patients

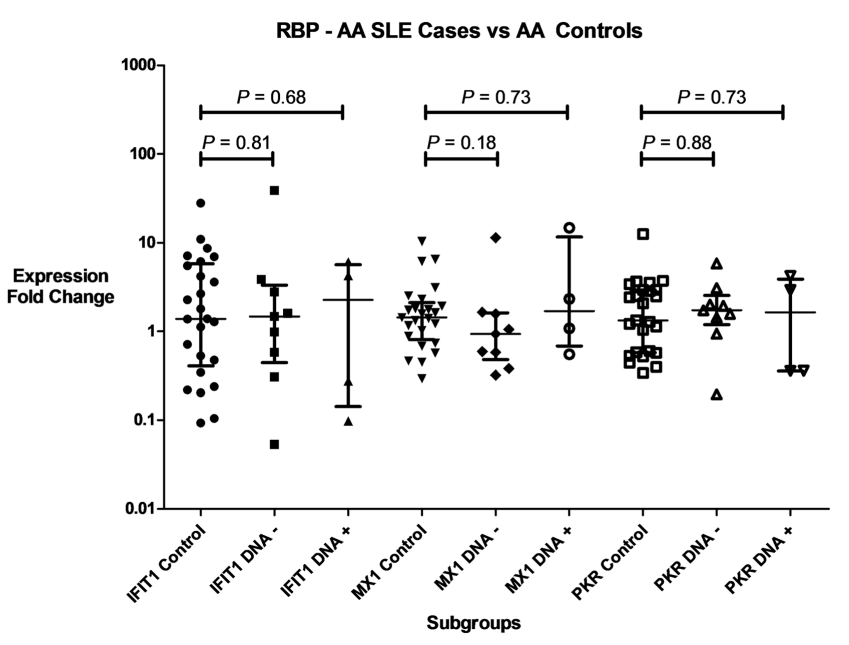

with anti-dsDNA antibodies (DNA+), and those who lack those antibodies (DNA-). Central tendency shown is a median, with error bars representing the interquartile range. $P$ values generated by Mann-Whitney $U$ test. pathogenic factors will be relevant in RBP- AA patients as compared to the RBP+ SLE patients. SLE is a complex autoimmune disease, and understanding heterogeneity in the molecular pathogenesis in lupus will be crucial in informing therapeutic and diagnostic strategies. This study demonstrates the relevance of careful patient characterization and including patients from more than one ancestral background in biological studies of SLE.

\section{AUTHOR'S CONTRIBUTIONS}

Kichul Ko participated in the design of the study and its coordination, screened for cases and controls, lead the statistical analysis, and drafted the manuscript. Yelena Koldobskaya helped screen for cases and controls, and collected microarray data. Elizabeth Rosenzweig helped generate qPCR data. Timothy B. Niewold was the senior scientist overseeing the study and helped with study design, statistical analysis, and manuscript drafting.

\section{ACKNOWLEDGMENTS}

Kichul Ko - Arthritis Foundation Clinical to Research Transition Award, Yelena Koldobskaya - none, Elizabeth Rosenzweig none, Timothy B. Niewold - Research grants from the NIH (R01 AR060861, K08 AI083790, Clinical Research Loan Repayment AI071651, CTSA Core Subsidy Grant, and CTSA Pilot Grants from UL1 RR024999), and Lupus Research Institute Novel Research Grant. 


\section{REFERENCES}

1. Hochberg MC. Updating the American College of Rheumatology revised criteria for the classification of systemic lupus erythematosus. Arthritis Rheum (1997) 40:1725. doi:10.1002/art.1780400928

2. Alarcon-Segovia D, AlarconRiquelme ME, Cardiel MH, Caeiro F, Massardo L, Villa AR, et al. Familial aggregation of systemic lupus erythematosus, rheumatoid arthritis, and other autoimmune diseases in 1,177 lupus patients from the GLADEL cohort. Arthritis Rheum (2005) 52:1138-47. doi:10.1002/art.20999

3. Rhodes B, Vyse TJ. The genetics of SLE: an update in the light of genome-wide association studies. Rheumatology (Oxford) (2008) 47:1603. doi:10.1093/rheumatology/ken247

4. Tsokos GC. Systemic lupus erythematosus. $N$ Engl $J$ Med (2011) 365:2110-21. doi:10.1056/NEJMra1100359

5. Weckerle CE, Niewold TB. The unexplained female predominance of systemic lupus erythematosus: clues from genetic and cytokine studies. Clin Rev Allergy Immunol (2011) 40:42-9. doi:10.1007/s12016-009-8192-4

6. Liu Z, Davidson A. Taming lupusa new understanding of pathogenesis is leading to clinical advances. Nat Med (2012) 18:871-82. doi:10. 1038/nm.2752

7. Deng Y, Tsao BP. Genetic susceptibility to systemic lupus erythematosus in the genomic era. Nat Rev Rheumatol (2010) 6:683-92. doi:10. 1038/nrrheum.2010.176

8. Mandel M, Achiron A. Gene expression studies in systemic lupus erythematosus. Lupus (2006) 15:451. doi:10.1191/0961203306lu2332oa

9. Koike T. The new era of autoimmune disease research. Arthritis Res Ther (2011) 13:113. doi:10.1186/ ar3335

10. Baechler EC, Batliwalla FM, Karypis G, Gaffney PM, Ortmann WA, Espe $\mathrm{KJ}$, et al. Interferon-inducible gene expression signature in peripheral blood cells of patients with severe lupus. Proc Natl Acad Sci U S A (2003) 100:2610-5. doi:10.1073/ pnas.0337679100

11. Bennett L, Palucka AK, Arce E, Cantrell V, Borvak J, Banchereau $\mathrm{J}$, et al. Interferon and granulopoiesis signatures in systemic lupus erythematosus blood. J Exp Med (2003) 197:711-23. doi:10. 1084/jem.20021553
12. Han GM, Chen SL, Shen N, Ye S, Bao CD, Gu YY. Analysis of gene expression profiles in human systemic lupus erythematosus using oligonucleotide microarray. Genes Immun (2003) 4:177. doi:10.1038/ sj.gene.6363966

13. Li QZ, Zhou J, Lian Y, Zhang B, Branch VK, Carr-Johnson F, et al. Interferon signature gene expression is correlated with autoantibody profiles in patients with incomplete lupus syndromes. Clin Exp Immunol (2010) 159:281-91. doi:10.1111/j. 1365-2249.2009.04057.x

14. Lee HM, Sugino H, Aoki C, Nishimoto N. Underexpression of mitochondrial-DNA encoded ATP synthesis-related genes and DNA repair genes in systemic lupus erythematosus. Arthritis Res Ther (2011) 13:R63. doi:10.1186/ar3317

15. Maas K, Chan S, Parker J, Slater A, Moore J, Olsen N, et al. Cutting edge: molecular portrait of human autoimmune disease. J Immunol (2002) 169:5.

16. Mandel M, Gurevich M, Pauzner R, Kaminski N, Achiron A. Autoimmunity gene expression portrait: specific signature that intersects or differentiates between multiple sclerosis and systemic lupus erythematosus. Clin Exp Immunol (2004) 138:164. doi:10.1111/j.13652249.2004.02587.x

17. Rus V, Chen H, Zernetkina V, Magder LS, Mathai S, Hochberg MC, et al. Gene expression profiling in peripheral blood mononuclear cells from lupus patients with active and inactive disease. Clin Immunol (2004) 112:231. doi:10.1016/j.clim. 2004.06.005

18. Niewold TB. Interferon alpha as a primary pathogenic factor in human lupus. J Interferon Cytokine Res (2011) 31:887-92. doi:10.1089/ jir.2011.0071

19. Bronson PG, Chaivorapol C, Ortmann W, Behrens TW, Graham RR. The genetics of type I interferon in systemic lupus erythematosus. Curr Opin Immunol (2012) 24:530-7. doi:10.1016/j.coi.2012.07.008

20. Blanco P, Palucka AK, Gill M, Pascual V, Banchereau J. Induction of dendritic cell differentiation by IFN-alpha in systemic lupus erythematosus. Science (2001) 294:1540-3. doi:10.1126/science. 1064890

21. Niewold TB, Clark DN, Salloum R, Poole BD. Interferon alpha in systemic lupus erythematosus. J Biomed Biotechnol (2010) 2010:948364. doi:10.1155/2010/948364
22. Niewold TB, Hua J, Lehman TJ, Harley JB, Crow MK. High serum IFN-alpha activity is a heritable risk factor for systemic lupus erythematosus. Genes Immun (2007) 8:492. doi:10.1038/sj.gene.6364408

23. Niewold TB, Adler JE, Glenn SB, Lehman TJ, Harley JB, Crow MK. Age- and sex-related patterns of serum interferon-alpha activity in lupus families. Arthritis Rheum (2008) 58:2113-9. doi:10.1002/art. 23619

24. Niewold TB. Interferon alphainduced lupus: proof of principle. J Clin Rheumatol (2008) 14:131-2. doi:10.1097/RHU. 0b013e318177627d

25. Nikpour M, Dempsey AA, Urowitz MB, Gladman DD, Barnes DA. Association of a gene expression profile from whole blood with disease activity in systemic lupus erythaematosus. Ann Rheum Dis (2008) 67:1069. doi:10.1136/ard. 2007.074765

26. Kirou KA, Lee C, George S, Louca K, Peterson MG, Crow MK. Activation of the interferon-alpha pathway identifies a subgroup of systemic lupus erythematosus patients with distinct serologic features and active disease. Arthritis Rheum (2005) 52:1491-503. doi:10.1002/ art.21031

27. Landolt-Marticorena C, Bonventi G, Lubovich A, Ferguson C, Unnithan T, Su J, et al. Lack of association between the interferonalpha signature and longitudinal changes in disease activity in systemic lupus erythematosus. Ann Rheum Dis (2009) 68:1440-6. doi:10.1136/ard.2008.093146

28. Petri M, Singh S, Tesfasyone $H$, Dedrick R, Fry K, Lal P, et al. Longitudinal expression of type I interferon responsive genes in systemic lupus erythematosus. Lupus (2009) 18:980-9. doi:10. 1177/0961203309105529

29. Hopkinson ND, Doherty M, Powell RJ. Clinical features and racespecific incidence/prevalence rates of systemic lupus erythematosus in a geographically complete cohort of patients. Ann Rheum Dis (1994) 53:675. doi:10.1136/ard.53. 10.675

30. Molina JF, Molina J, Garcia C, Gharavi AE, Wilson WA, Espinoza LR. Ethnic differences in the clinical expression of systemic lupus erythematosus: a comparative study between African-Americans and Latin Americans. Lupus (1997) 6:63. doi:10.1177/096120339700600109
31. Alarcon GS, Friedman AW, Straaton KV, Moulds JM, Lisse J, Bastian HM, et al. Systemic lupus erythematosus in three ethnic groups: III. A comparison of characteristics early in the natural history of the LUMINA cohort. LUpus in MInority populations: NAture vs. Nurture. Lupus (1999) 8:197-209. doi: 10.1191/096120399678847704

32. Cooper GS, Parks CG, Treadwell EL, St Clair EW, Gilkeson GS, Cohen PL, et al. Differences by race, sex and age in the clinical and immunologic features of recently diagnosed systemic lupus erythematosus patients in the southeastern United States. Lupus (2002) 11:161-7. doi:10. 1191/0961203302lu161oa

33. Ramos PS, Kelly JA, Gray-McGuire C, Bruner GR, Leiran AN, Meyer $\mathrm{CM}$, et al. Familial aggregation and linkage analysis of autoantibody traits in pedigrees multiplex for systemic lupus erythematosus. Genes Immun (2006) 7:417-32. doi: 10.1038/sj.gene.6364316

34. Kariuki SN, Franek BS, Kumar AA, Arrington J, Mikolaitis RA, Utset TO, et al. Trait-stratified genomewide association study identifies novel and diverse genetic associations with serologic and cytokine phenotypes in systemic lupus erythematosus. Arthritis Res Ther (2010) 12:R151. doi:10.1186/ar3101

35. Bastian HM, Roseman JM, McGwin G Jr, Alarcon GS, Friedman AW, Fessler BJ, et al. Systemic lupus erythematosus in three ethnic groups. XII. Risk factors for lupus nephritis after diagnosis. Lupus (2002) 11:152. doi:10.1191/ 0961203302lu158oa

36. Sanchez E, Comeau ME, Freedman BI, Kelly JA, Kaufman KM, Langefeld CD, et al. Identification of novel genetic susceptibility loci in African American lupus patients in a candidate gene association study. Arthritis Rheum (2011) 63:3493-501. doi:10. 1002/art.30563

37. Pothlichet J, Niewold TB, Vitour D, Solhonne B, Crow MK, Si-Tahar M. A loss-of-function variant of the antiviral molecule MAVS is associated with a subset of systemic lupus patients. EMBO Mol Med (2011) 3:142-52. doi:10.1002/ emmm.201000120

38. Lodolce JP, Kolodziej LE, Rhee L, Kariuki SN, Franek BS, McGreal $\mathrm{NM}$, et al. African-derived genetic polymorphisms in TNFAIP3 mediate risk for autoimmunity. J Immunol (2010) 184:7001-9. doi:10.4049/jimmunol.1000324 
39. Harley ITW, Niewold TB, Stormont RM, Kaufman KM, Glenn SB, Franek BS, et al. The role of genetic variation near interferonkappa in systemic lupus erythematosus. J Biomed Biotechnol (2010) 2010:706825. doi:10.1155/ 2010/706825

40. Weckerle CE, Franek BS, Kelly JA, Kumabe M, Mikolaitis RA, Green SL, et al. Network analysis of associations between serum interferon-alpha activity, autoantibodies, and clinical features in systemic lupus erythematosus. Arthritis Rheum (2011) 63:1044-53. doi:10.1002/ art.30187

41. Ko K, Franek BS, Marion M, Kaufman KM, Langefeld CD, Harley JB, et al. Genetic ancestry, serum interferon-alpha activity, and autoantibodies in systemic lupus erythematosus. $J$ Rheumatol (2012) 39:1238-40. doi:10.3899/jrheum.111467

42. Tan EM, Cohen AS, Fries JF, Masi AT, McShane DJ, Rothfield NF, et al. The 1982 revised criteria for the classification of systemic lupus erythematosus. Arthritis Rheum (1982) 25:1271. doi:10. 1002/art.1780251101

43. Cham CM, Ko K, Niewold TB. Interferon regulatory factor 5 in the pathogenesis of systemic lupus erythematosus. Clin Dev Immunol
(2012) 2012:780436. doi:10.1155/ 2012/780436

44. Lovgren T, Eloranta ML, Bave U, Alm GV, Ronnblom L. Induction of interferon-alpha production in plasmacytoid dendritic cells by immune complexes containing nucleic acid released by necrotic or late apoptotic cells and lupus IgG. Arthritis Rheum (2004) 50:1861. doi:10.1002/art.20254

45. Lovgren T, Eloranta ML, Kastner B, Wahren-Herlenius M, Alm $\mathrm{GV}$, Ronnblom L. Induction of interferon-alpha by immune complexes or liposomes containing systemic lupus erythematosus autoantigen- and Sjogren's syndrome autoantigen-associated RNA. Arthritis Rheum (2006) 54:1917. doi:10.1002/art.21893

46. Salloum R, Franek BS, Kariuki SN, Rhee L, Mikolaitis RA, Jolly $\mathrm{M}$, et al. Genetic variation at the IRF7/PHRF1 locus is associated with autoantibody profile and serum interferon-alpha activity in lupus patients. Arthritis Rheum (2010) 62:553-61. doi:10.1002/art. 27182

47. Niewold TB, Kelly JA, Kariuki SN, Franek BS, Kumar AA, Kaufman KM, et al. IRF5 haplotypes demonstrate diverse serological associations which predict serum interferon alpha activity and explain the majority of the genetic association with systemic lupus erythematosus. Ann Rheum Dis (2012) 71:463-8. doi:10.1136/ annrheumdis-2011-200463

48. Koldobskaya Y, Ko K, Kumar AA, Agik S, Arrington J, Kariuki SN, et al. Gene-expression-guided selection of candidate loci and molecular phenotype analyses enhance genetic discovery in systemic lupus erythematosus. Clin Dev Immunol (2012) 2012:682018. doi:10.1155/ 2012/682018

49. Wu T, Mohan C. Lupus nephritis - alarmins may sound the alarm? Arthritis Res Ther (2012) 14:129.

50. Robinson T, Kariuki SN, Franek BS, Kumabe M, Kumar AA, Badaracco $\mathrm{M}$, et al. Autoimmune disease risk variant of IFIH1 is associated with increased sensitivity to IFN-alpha and serologic autoimmunity in lupus patients. Jmmunol (2011) 187:1298-303. doi:10.4049/ jimmunol.1100857

51. Kariuki SN, Kirou KA, MacDermott EJ, Barillas-Arias L, Crow MK, Niewold TB. Cutting edge: autoimmune disease risk variant of STAT4 confers increased sensitivity to IFNalpha in lupus patients in vivo. $J$ Immunol (2009) 182:34-8.

52. Lichtman EI, Helfgott SM, Kriegel MA. Emerging therapies for systemic lupus erythematosus - focus on targeting interferon-alpha. Clin
Immunol (2012) 143:210-21. doi: 10.1016/j.clim.2012.03.005

Conflict of Interest Statement: The authors declare that the research was conducted in the absence of any commercial or financial relationships that could be construed as a potential conflict of interest.

Received: 03 July 2013; accepted: 16 September 2013; published online: 01 October 2013.

Citation: Ko K, Koldobskaya Y, Rosenzweig E and Niewold TB (2013) Activation of the interferon pathway is dependent upon autoantibodies in African-American SLE patients, but not in European-American SLE patients. Front. Immunol. 4:309. doi: 10.3389/fimmu.2013.00309

This article was submitted to Molecular Innate Immunity, a section of the journal Frontiers in Immunology.

Copyright (c) 2013 Ko, Koldobskaya, Rosenzweig and Niewold. This is an open-access article distributed under the terms of the Creative Commons Attribution License (CC BY). The use, distribution or reproduction in other forums is permitted, provided the original author(s) or licensor are credited and that the original publication in this journal is cited, in accordance with accepted academic practice. No use, distribution or reproduction is permitted which does not comply with these terms. 